was presented at the last annual conference. Anyone who is interested in proposing new subject headings (including new genre/form terms in religion) as well as new LC classification numbers is invited to participate in this webinar. The webinar is scheduled for Wednesday, May 17, at 2:00 pm EST. Consult the February ATLA Newsletter for more information.

Submitted by

Richard Lammert, Technical Services and Systems Librarian

Kroemer Library, Concordia Theological Seminary

\title{
SELECTED ARTICLES FROM CURRENT LIBRARY JOURNALS
}

Avery, Joshua M. "Implementing an Open Source Integrated Library System (ILS) in a Special Focus Institution." Digital Library Perspectives 32, no. 4 (October 2016): 287-298.

Clair, Kevin. "Technical Debt as an Indicator of Library Metadata Quality." D-Lib Magazine 22, no. 11/12 (November 2016): 1, doi: 10.1045/november2016-clair. http://www.dlib.org/dlib/november16/clair/11clair.html

Fallaw, Colleen, et al. "Overly Honest Data Repository Development." Code4lib Journal no. 34(October 2016): 1. http:// journal.code4lib.org/articles/11980

Godby, Carol Jean and Karen Smith-Yoshimura. "From Records to Things: Managing theTransition from Legacy Library Metadata to Linked Data." Bulletin of The Association For Information Science E Technology 43, no. 2 (December 2016): 18-23.

Kelley, Steve. "The Smaller Library Staff 's Perspective on BIBFRAME." Technicalities 36, no. 6 (November 2016): 8-11.

Long, Chris Evin. "Disambiguating the Departed." Library Resources E Technical Services 60, no. 4 (October 2016): 236247.

McGettigan, Katie. "Catalogs as Big Data for Nineteenth-Century Publishers' Series." Past is Present: The American Antiquarian Society Blog. November 1, 2016. http://pastispresent.org/2016/digital-humanities-2/catalogs-as-bigdata-for-nineteenth-century-publishers-series/

Perez-Lizano, Elena. "Implementing Resource, Description, and Access in a Time of Change in the Small Academic Library." Technical Services Quarterly 33, no. 4 (October 2016): 353-370.

Qiang, Jin, Jim Hahn, and Gretchen Croll. "BIBFRAME Transformation for Enhanced Discovery." Library Resources E Technical Services 60, no. 4 (October 2016): 223-235.

Sandberg, Jane and Qiang Jin. "How Should Catalogers Provide Authority Control for Journal Article Authors? Name Identifiers in the Linked Data World." Cataloging \& Classification Quarterly 54, no. 8 (November 2016): 537-552.

Sjökvist, Peter. "Transcription in Rare Books Cataloging." Cataloging E Classification Quarterly 54, no. 5/6 (July 2016): 377-383.

Stewart, Morag and Cheryl Aine Morrison. "Notes on Operations Breaking Ground: Consortial Migration to a NextGeneration ILS and Its Impact on Acquisitions Workflows." Library Resources E Technical Services 60, no. 4 (October 2016): 259-269.

Wallheim, Henrik. "From Complex Reality to Formal Description: Bibliographic Relationships and Problems of Operationalization in RDA." Cataloging E Classification Quarterly 54, no. 7 (October 2016): 483-503.

Welsh, Anne. "MarcEdit for Mac and the Rare Books Researcher." Catalogue E̊ Index no. 184 (September 2016): 2-13.

Submitted by

Anna Appleman, Cataloger

John Bulow Campbell Library, Columbia Theological Seminary 